\title{
Optimization of Pyrolysis Operating Condition for Deriving Corn Starch Heterogeneous Acid Catalyst for Biodiesel Production
}

\author{
Herry Santoso ${ }^{1}$, Christ Michael ${ }^{1}$, Hillman Wira ${ }^{1} \&$ Maria Inggrid ${ }^{1}$ \\ ${ }^{1}$ Chemical Engineering Department, Parahyangan Catholic University, Indonesia \\ Correspondence: Herry Santoso, Chemical Engineering Department, Parahyangan Catholic University, Bandung, \\ 40141, Indonesia. E-mail: hsantoso@unpar.ac.id
}

Received: May 4, 2015

Accepted: June 5, 2015

Online Published: June 30, 2015

doi:10.5539/mas.v9n7p61

URL: http://dx.doi.org/10.5539/mas.v9n7p61

\begin{abstract}
Biodiesel can be produced from various oils and fats. Due to possibility of diversion of edible oils from feed stocks to raw materials for biodiesel production, which may lead to food crisis, it is preferable to choose non-edible oils as raw material for biodiesel production. As a country rich in natural resources, Indonesia has a vast amount and variety of non-edible fatty-oil production plants. However, non-edible oils usually have high free fatty acid (FFA) contents. Oils with high FFA contents cannot be converted directly to biodiesel using a conventional alkaline catalyzed process due to saponification problem. To avoid this problem, the high FFA contents in the oils must be reduced via esterification process using acid catalyst. The use of homogeneous acid catalyst in this process can be very corrosive and not environmentally friendly while the use of commercially available heterogeneous acid catalyst can be very expensive. In this research, a heterogeneous acid catalyst suitable for biodiesel production will be derived from corn starch through pyrolysis followed by sulphonation processes. The purpose of this research is to study the effects of pyrolysis temperature and time to the acid density of the catalyst and the activity of the catalyst in the esterification of oleic acid using a $2^{2}$ factorial design with 3 center points experimental design. It is found that the catalyst obtained from pyrolysis at $400^{\circ} \mathrm{C}$ for 15 hours has the optimum- $\mathrm{HSO}_{3}$ content of $5.9 \%$ which corresponds to the highest average conversion of the esterification of oleic acid of $97.45 \%$.
\end{abstract}

Keywords: heterogeneous acid catalyst, corn starch, pyrolysis, sulphonation, operating condition

\section{Introduction}

Biodiesel is an alternative fuel for diesel engine that can be produced by transesterification reaction of various plant and animal oils and fats with short-chain alcohols in the presence of a catalyst (Marchetti et al., 2007; Ibeto et al., 2011). Currently, the main resources for world biodiesel production come from edible oils, such as rapeseed, soybean, sunflower, and palm oil (Ahmia et al., 2014). Due to possibility of diversion of edible oils from feed stocks to raw materials for biodiesel production, which may lead to food crisis, it is preferable to choose non-edible oils as raw material for biodiesel production (Refaat, 2010; Pimentel et al., 2009).

As a country rich in natural resources, Indonesia has a vast amount and variety of non-edible fatty-oil production plants. However, non-edible oils usually have high free fatty acid (FFA) contents (Mathiyazhagan et al., 2011). Oils with high FFA contents cannot be converted directly to biodiesel using a conventional alkaline catalyzed process due to saponification problem (Guo and Leung, 2003). To avoid this problem, the high FFA contents in the oils must be reduced via esterification process using acid catalyst (Wang et al., 2007; Van Gerpen and Knothe, 2005; Zhang et al., 2003).

The use of homogeneous acid catalyst in this process can be very corrosive and not environmentally friendly while the use of commercially available heterogeneous acid catalyst can be very expensive. An efficient and ecologically friendly solid acid catalyst that can be used in biodiesel production can be made by sulphonating incompletely carbonized natural products, such as sugar, starch, or cellulose. This catalyst is robust and recyclable. The activity of this catalyst exceeds the activity of other solid acid catalysts that have been tested for biodiesel production (Toda et al., 2005).

The activity of catalysts made from several natural products (i.e. D-glucose, sucrose, starch, and cellulose) has been investigated. It is found that catalyst made from starch has a higher activity compared to catalysts made 
from other natural products (Lou et al., 2008). Since all starches are made up of varying proportions of amylose and amylopectin, the activity of catalysts made from different types of starches might be different. The activity of catalysts made from a mixture of glucose with different types of starches that have different proportions of amylose and amylopectin has also been investigated. It is found that the catalyst made from a mixture of glucose with starch that has higher amylopectin content has a higher activity compared to the catalyst made from a mixture of glucose with starch that has lower amylopectin content (Chen and Fang, 2011).

The pyrolysis and sulphonation operating conditions used to synthesize the solid acid catalyst from a particular natural product differ significantly in the literature. The pyrolysis temperature is in the range of 300 to $700^{\circ} \mathrm{C}$ while the pyrolysis time is in the range of 1 to 20 hours. For sulphonation, the temperature reported in the literature is in the range of 100 to $210^{\circ} \mathrm{C}$ while the time is in the range of 2 to 20 hours (Zong et al., 2007; Lou et al., 2008; Shu et al., 2010; Chen and Fang, 2011; Pua et al., 2011). The pyrolysis and sulphonation operating conditions used to synthesize the solid acid catalyst may have a significant effect on the activity of the catalyst (Lou et al., 2008). However, the best pyrolysis and sulphonation operating conditions are still tenuous.

In this study, a heterogeneous acid catalyst suitable for biodiesel production was derived from corn starch through pyrolysis followed by sulphonation processes. The purpose of this research is to study the effects of pyrolysis temperature and time to the acid density of the catalyst and the activity of the catalyst in the esterification of oleic acid using a $2^{2}$ factorial design with 3 center points experimental design.

\section{Materials and Method}

\subsection{Materials}

The heterogeneous acid catalyst suitable for biodiesel production in this study was derived from corn starch. The corn starch was obtained from Mekar Sari, Yogyakarta and had amylose and amylopectin contents of $12.65 \%$ and $72.35 \%$, respectively. The methanol (p.A. $>99.8 \%$ ) and oleic acid (99\%) used in the esterification process was obtained from Bratachem, Bandung. The rubber seeds used in biodiesel production were obtained from Sukabumi, West Java.

\subsection{Catalyst Preparation}

The solid acid catalyst was prepared by heating corn starch at a particular temperature for a specified time under $\mathrm{N}_{2}$ flow to form a rigid carbon material consisting of small polycyclic aromatic carbon sheets in a three dimensional $\mathrm{sp}^{3}$-bonded structure. To find the optimum pyrolysis operating condition for deriving the corn starch heterogeneous acid catalyst for biodiesel production, the pyrolysis operating condition was varied at different pyrolysis temperatures $\left(350,400\right.$, and $\left.450^{\circ} \mathrm{C}\right)$ and pyrolysis times $\left(12.5,15\right.$, and 17.5 hours) using a $2^{2}$ factorial design with 3 center points experimental design.

The resulting incomplete carbonized material was ground to a powder and then sulphonated using concentrated sulfuric acid (>96\%) at the temperature of $150^{\circ} \mathrm{C}$ for 15 hours under $\mathrm{N}_{2}$ atmosphere to introduce $-\mathrm{SO}_{3} \mathrm{H}$ to the polycyclic aromatic carbon rings. After sulphonation, the mixture was cooled down to room temperature and diluted with distilled water. The solid material was then separated by filtration and washed thoroughly with hot distilled water until the sulfate ions were no longer detected in the wash water. The prepared catalyst was then dried at $110^{\circ} \mathrm{C}$ for 48 hours in an oven.

\subsection{Catalytic Activity Testing in Esterification Reaction}

To test the activity of the prepared catalysts, esterification reactions between methanol and oleic acid using the prepared catalysts were performed. The esterification reactions were carried out in an erlenmeyer flask equipped with a water bath, a temperature controller, a magnetic stirrer, and a reflux condenser. The reaction temperature was at $80^{\circ} \mathrm{C}$ with the reaction time of 3 hours, the amount of catalyst used of $5 \%$-wt., and the molar ratio of methanol to oleic acid of 10:1.

\subsection{Biodiesel Production from Rubber Seed Oil}

The rubber seed oil was obtained from the rubber seed kernels by mechanical extraction method using a hydraulic press machine operated at $70^{\circ} \mathrm{C}$ and 100 bars with the pressing time of 60 minutes. To separate gums from the oil, the rubber seed oil was degummed at $100^{\circ} \mathrm{C}$ using $0.25 \%$-wt. of $85 \%$ phosphoric acid. To separate impurities from the oil, the rubber seed oil was bleached at $100^{\circ} \mathrm{C}$ for 20 minutes using $1 \%$ wt. dry activated bentonite. To reduce the iodine number in the oil, the rubber seed oil was electro-catalytically hydrogenated using potassium electrolyte solution and methanol formate.

The rubber seed oil that had been degummed, bleached, and electro-catalytically hydrogenated, was converted into biodiesel by reacting it with methanol. The best catalyst in the esterification reaction tests was used in this 
reaction. The reaction was carried out in an erlenmeyer flask equipped with a water bath, a temperature controller, a magnetic stirrer, and a reflux condenser. The reaction temperature was at $80^{\circ} \mathrm{C}$ with the reaction time of 10 hours, the amount of catalyst used of $10 \%$-wt., and the molar ratio of methanol to oleic acid of 30:1.

\subsection{Analytical Method}

Scanning Electron Microscopy (SEM) was used to examine the surface morphology and the particle size of the prepared catalysts while Energy Dispersive X-ray Spectroscopy (EDS) was used to identify the chemical composition of the catalysts. The pure spectrum EDS analysis gave the compositions of the catalyst in terms of pure components, such as carbon, oxygen, and sulfur. The oxide spectrum EDS analysis gave the compositions of oxide compounds in the catalyst, i.e. $-\mathrm{SO}_{3}$ group. Since EDS analysis could not detect the presence of hydrogen, the $-\mathrm{SO}_{3} \mathrm{H}$ group in the prepared catalysts was estimated by assuming that all the $-\mathrm{SO}_{3}$ group in the derived catalyst are in the form of $-\mathrm{SO}_{3} \mathrm{H}$ group. By adding one hydrogen to each $-\mathrm{SO}_{3}$ group, the \%-wt. of the $-\mathrm{SO}_{3} \mathrm{H}$ group in the prepared catalysts then can be estimated by simple calculation.

The amount of oleic acid in a sample can be determined using titration method. In the titration method, the oleic acid sample was dissolved in isopropyl alcohol (IPA) and then titrated using $\mathrm{KOH}$. Based on the amount of $\mathrm{KOH}$ required to neutralize the oleic acid dissolved in IPA solution and the amount of $\mathrm{KOH}$ required to neutralize the IPA blank solution, the amount of oleic acid in the sample can be calculated as follows:

$$
n=(v-b) \times N
$$

where $v$ is the volume of $\mathrm{KOH}$ required to neutralizes the oleic acid dissolved in IPA solution, $b$ is the volume of $\mathrm{KOH}$ required to neutralized the IPA blank solution, $N$ is the normality of $\mathrm{KOH}$ solution. Using the amounts of oleic acid before and after the esterification reaction, the conversion of oleic acid can be easily calculated.

The properties of rubber seed oil, i.e. the density, the viscosity, and the free fatty acid (FFA) content are determined using pycnometer, Ostwald viscometer at $40^{\circ} \mathrm{C}$, and titration method, respectively. Using titration data, the FFA content can be calculated as follows

$$
F F A(\%)=\frac{(v-b) \times N \times M W_{\mathrm{FFA}}}{w} \times 100 \%
$$

where $v, b$, and $N$ are analogous to the ones mentioned above, while $M W_{\mathrm{FFA}}$ is the average molecular weight of the free fatty acids in the rubber seed oil, and $w$ is the weight of rubber seed oil in the titration sample.

\section{Results and Discussion}

The prepared catalysts were analyzed using Scanning Electron Microscopy (SEM) to examine the surface morphology and the particle size of the prepared catalysts and using Energy Dispersive X-ray Spectroscopy (EDS) to identify the chemical composition of the catalysts. Figure 1 and Figure 2 show one of the SEM and EDS analysis results of the prepared catalysts, respectively.

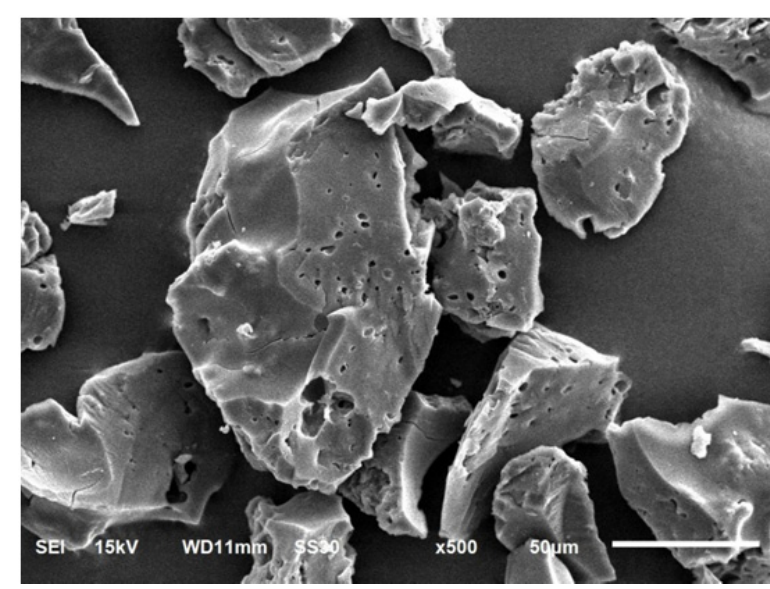

(a)

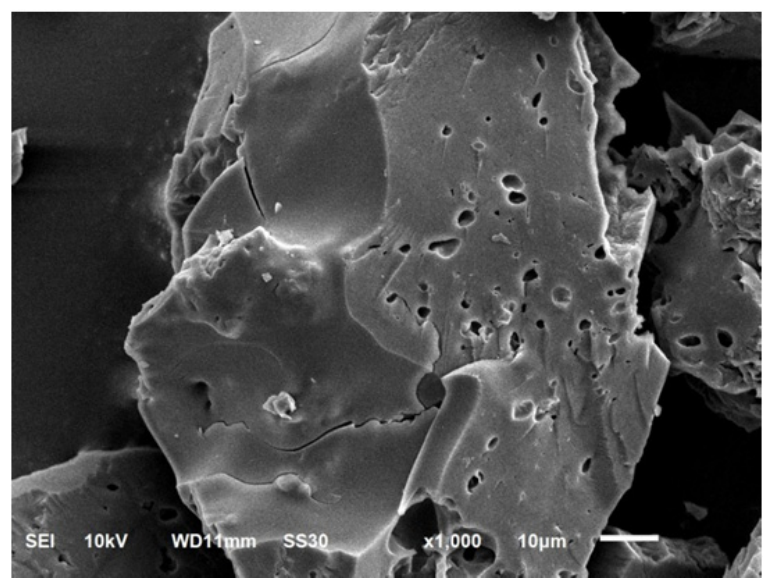

(b)

Figure 1. The SEM analysis results with: (a) 500x magnification and (b) 1000x magnification 


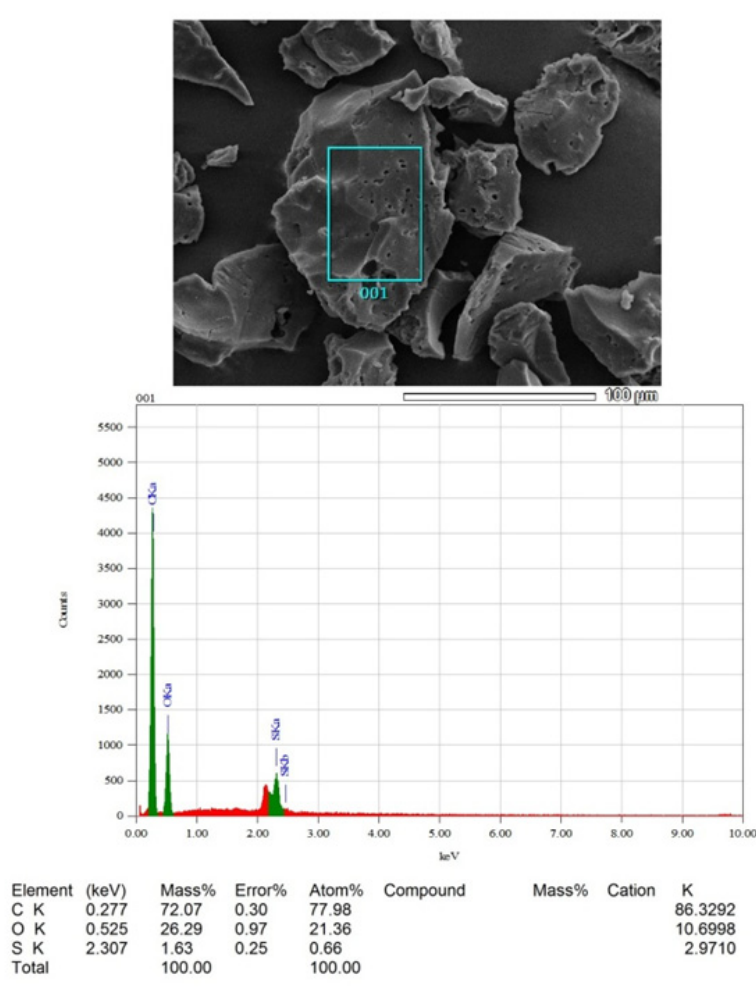

(a)

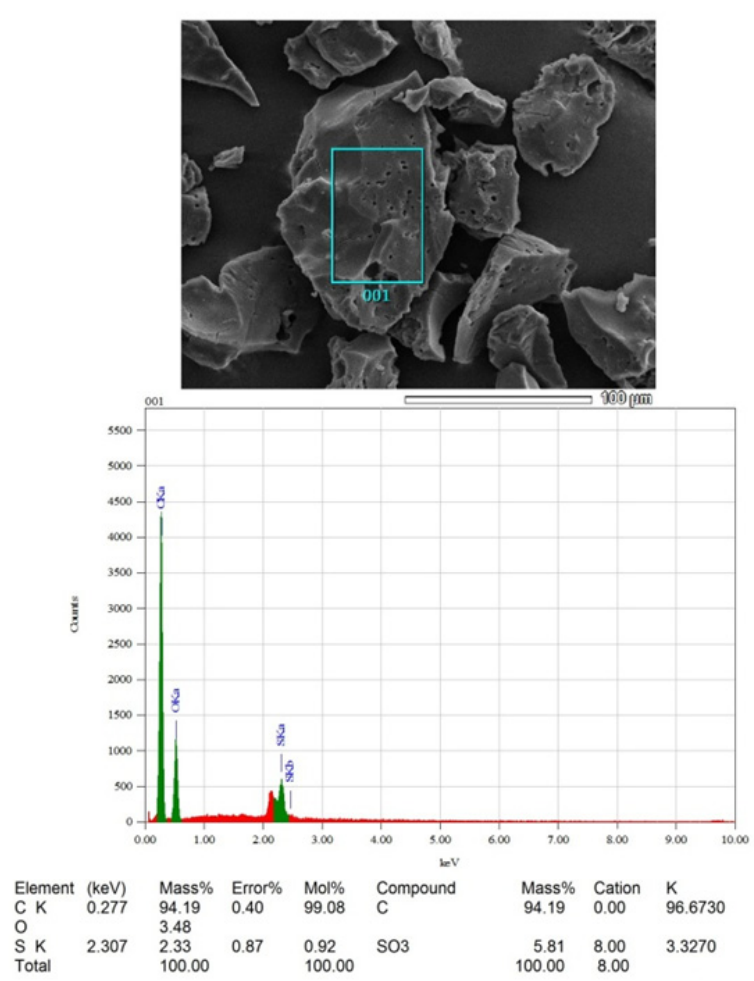

(b)

Figure 2. The EDS analysis results with: (a) pure spectrum and (b) oxide spectrum

From SEM analysis results, it can be seen that the particle sizes of the prepared catalysts were uneven and reach micrometer dimensions. The catalyst particles did not significantly aggregate and the surface of the particles were relatively smooth. No significant difference in morphology was observed among the prepared catalysts.

The prepared catalysts contained around $72.07 \%$ carbon, $26.29 \%$ oxygen, and $1.63 \%$ sulfur (Figure $2 \mathrm{a}$ ). The oxide compound between sulfur and oxygen in the catalyst was identified as $\mathrm{SO}_{3}$ (Figure 2b). The EDS analysis could not detect the presence of hydrogen. Hence, the EDS analysis only reported the presence of $-\mathrm{SO}_{3}$ (not $-\mathrm{SO}_{3} \mathrm{H}$ ) group in the catalyst. According to Lou et al. (2008), based on XPS analysis, essentially all the sulfur in the carbohydrate-derived catalyst is contained in $-\mathrm{SO}_{3} \mathrm{H}$ group. Table 1 shows the estimated \%-wt. of the $-\mathrm{SO}_{3} \mathrm{H}$ group in the prepared catalysts based on the EDS analysis results. In order to identify which pyrolysis operating variables that have significant effects on the $-\mathrm{SO}_{3} \mathrm{H}$ group content in the catalyst, the Analysis of Variance (ANOVA) was conducted. The ANOVA result is presented in Table 2.

Table 1. Estimated \%-wt. of the $-\mathrm{SO}_{3} \mathrm{H}$ group in the prepared catalysts

\begin{tabular}{rrrrrr}
\hline No. & $\begin{array}{r}\text { Pyrolysis } \\
\text { Time } \\
(\text { hours })\end{array}$ & $\begin{array}{r}\text { Pyrolysis } \\
\text { Temperature } \\
\left({ }^{\circ} \mathrm{C}\right)\end{array}$ & $\begin{array}{r}\text { Sulphonation } \\
\text { Time (hours) }\end{array}$ & $\begin{array}{r}\text { Sulphonation } \\
\text { Temperature }\left({ }^{\circ} \mathrm{C}\right)\end{array}$ & $\begin{array}{r}\text { Estimated } \\
-\mathrm{SO}_{3} \mathrm{H} \\
(\% \text {-wt. })\end{array}$ \\
\hline 1 & 12.5 & 350 & 15 & 150 & 5.8868 \\
2 & 17.5 & 350 & 15 & 150 & 3.9424 \\
3 & 12.5 & 450 & 15 & 150 & 6.0121 \\
4 & 17.5 & 450 & 15 & 150 & 5.6083 \\
5 & 15 & 400 & 15 & 150 & 5.8863 \\
6 & 15 & 400 & 15 & 150 & 5.9123 \\
\hline
\end{tabular}

Table 2. Analysis of variance

\begin{tabular}{llllll}
\hline Source & Sum of Squares & DOF & Mean Square & F-value & p-value \\
\hline
\end{tabular}




\begin{tabular}{lcccccc}
\hline Model & 2.77 & 3 & 0,92 & 2714.70 & 0.0141 & significant \\
A- Pyrolysis Time & 1.38 & 1 & 1.38 & 4047.59 & 0.0100 & significant \\
B- Pyrolysis Temperature & 0.80 & 1 & 0.80 & 2354.66 & 0.0131 & significant \\
AB & 0.59 & 1 & 0.59 & 1741.86 & 0.0153 & significant \\
Curvature & 0.38 & 1 & 0.38 & 1128.32 & 0.0189 & significant \\
Pure Error & 0.00034 & 1 & 0.00034 & & & \\
Cor Total & 3.16 & 5 & & & & \\
\hline
\end{tabular}

The p-values for Factor A, Factor B, and Factor AB were all smaller than 0.05 . These indicate that the pyrolysis time, the pyrolysis temperature, and interaction between these two variables affect the $-\mathrm{SO}_{3} \mathrm{H}$ group content in the prepared catalyst significantly. Furthermore, the curvature also had a p-value smaller than 0.05 . This indicates that there are a significant curvature in the response of the $-\mathrm{SO}_{3} \mathrm{H}$ group content in the prepared catalyst inside the variable ranges selected in the experiment. This means the variable ranges selected in the experiment are in the optimum ranges.

Figure 3 shows the interaction plot between pyrolysis time and pyrolysis temperature with its corresponding center points for the $-\mathrm{SO}_{3} \mathrm{H}$ group content in the prepared catalyst. From Figure 3, it can be seen that the average $-\mathrm{SO}_{3} \mathrm{H}$ group content in the prepared catalyst remained the same as the pyrolysis time increased from 12.5 to 15 hours. However, the average $-\mathrm{SO}_{3} \mathrm{H}$ group content in the prepared catalyst started to decrease significantly as the pyrolysis time increased from 15 to 17.5 hours. This indicates that increasing the pyrolysis time above 15 hours would have an adversely effect on the ability of the incompletely carbonized material to adsorb the $-\mathrm{SO}_{3} \mathrm{H}$ group during the sulphonation process. At a longer pyrolysis time, the incompletely carbonized material tends to form a more rigid structure due to the growth of larger polycyclic aromatic carbon sheets and the stacking of carbon sheets that restricts its ability to adsorb the $-\mathrm{SO}_{3} \mathrm{H}$ group.

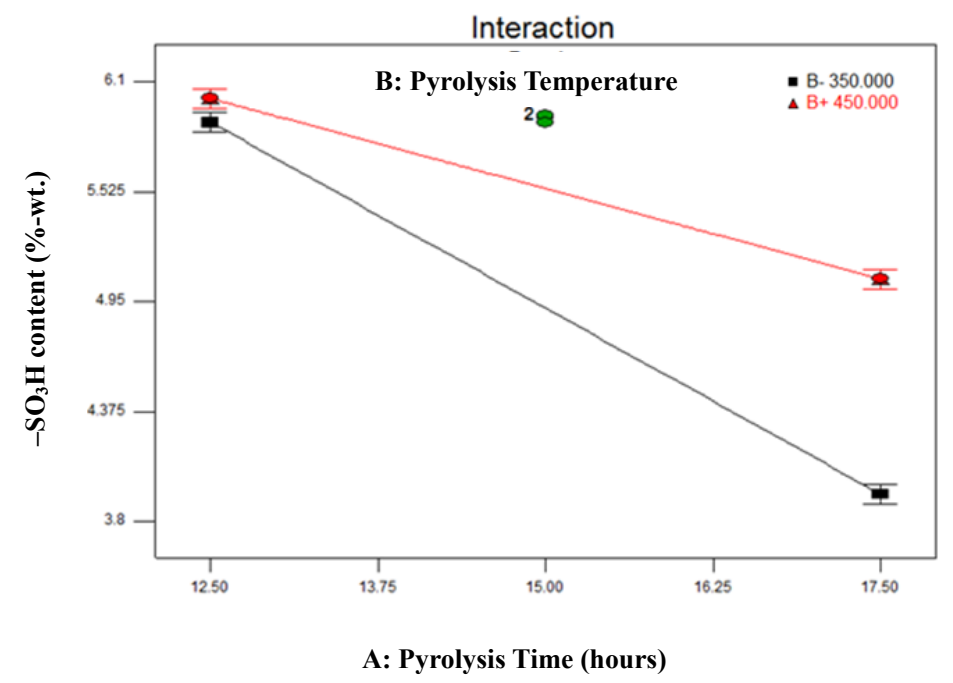

Figure 3. Effects of pyrolysis variables on the $-\mathrm{SO}_{3} \mathrm{H}$ group content in the prepared catalyst

Furthermore, the average $-\mathrm{SO}_{3} \mathrm{H}$ group content in the prepared catalyst increased as the pyrolysis temperature increased from 350 to $400^{\circ} \mathrm{C}$ and then slightly decreased as the temperature increased from 400 to $450^{\circ} \mathrm{C}$. At a lower pyrolysis temperature, the incompletely carbonized material tends to form a soft aggregate of small polycyclic aromatic carbon with $-\mathrm{SO}_{3} \mathrm{H}$ group. Therefore, the $-\mathrm{SO}_{3} \mathrm{H}$ group can be easily leached out from the catalyst during the preparation of the catalyst (Lou et al., 2008). At a higher temperature the incompletely carbonized material tends to form a more rigid structure as mentioned above due to the growth of larger polycyclic aromatic carbon sheets and the stacking of carbon sheets that restricts its ability to adsorb the $-\mathrm{SO}_{3} \mathrm{H}$ group (Kang, et al, 2013; Lou et al., 2008).

To test the activity of the prepared catalysts, esterification reactions between methanol and oleic acid using the prepared catalysts were performed. The prepared catalysts that had a higher activity would give a higher oleic acid conversion when used in the esterification reaction tests. The result of the esterification reaction tests is presented in Table 3. In order to identify which pyrolysis operating variables that had significant effects on the 
activity of the prepared catalyst, the Analysis of Variance (ANOVA) was conducted. The ANOVA result is presented in Table 4.

The p-values for Factor A and Factor B were smaller than 0.05. These indicate that the pyrolysis time and the pyrolysis temperature affect the activity of the prepared catalysts significantly. The interaction between these two variables does not affect the activity of the prepared catalysts since its p-value was greater than 0.05 . Furthermore, the curvature had a p-value smaller than 0.05 , indicating that there is a significant curvature in the response of the activity of the prepared catalysts inside the variable ranges selected in the experiment. This means the variable ranges selected in the experiment are in the optimum ranges.

The interaction plot between pyrolysis time and pyrolysis temperature with its corresponding center points for the activity of the prepared catalyst is shown in Figure 4. The average activity of the prepared catalysts increased as the pyrolysis time increased from 12.5 to 15 hours. This result is different from the previous result, which indicates that the average $-\mathrm{SO}_{3} \mathrm{H}$ group content in the prepared catalyst remains the same as the pyrolysis time increases from 12.5 to 15 hours. At a shorter pyrolysis time, the formation of the polycyclic aromatic carbon rings in the incompletely carbonized material is imperfect. Sulphonating this carbon material may result in a non-uniform distribution of the $-\mathrm{SO}_{3} \mathrm{H}$ group in the catalyst. Some parts of the catalyst may have a high $-\mathrm{SO}_{3} \mathrm{H}$ group content, while the other parts may have a low $-\mathrm{SO}_{3} \mathrm{H}$ group content. Therefore, the overall $-\mathrm{SO}_{3} \mathrm{H}$ group content in the catalyst might be lower than the $-\mathrm{SO}_{3} \mathrm{H}$ group content estimated by the EDS analysis result. As the pyrolysis time increased from 15 to 17.5 hours, the average activity of the prepared catalysts decreased accordingly due to the decrease of the $-\mathrm{SO}_{3} \mathrm{H}$ group in the prepared catalysts.

The activity of the prepared catalysts remained the same as the pyrolysis temperature increased from 350 to $400^{\circ} \mathrm{C}$ and then decreased as the temperature increased from 400 to $450^{\circ} \mathrm{C}$. As mentioned above, at a lower pyrolysis temperature, the incompletely carbonized material tends to form a soft aggregate of small polycyclic aromatic carbon with $-\mathrm{SO}_{3} \mathrm{H}$ group. Therefore, the $-\mathrm{SO}_{3} \mathrm{H}$ group can also be easily leached out from the catalyst to the reaction mixture during the esterification reaction tests resulting in an unexpectedly high catalytic performance compared to its $-\mathrm{SO}_{3} \mathrm{H}$ group content. At a higher temperature the incompletely carbonized material tends to form a more rigid structure as mentioned above due to the growth of larger polycyclic aromatic carbon sheets and the stacking of carbon sheets that restricts its ability to adsorb the $-\mathrm{SO}_{3} \mathrm{H}$ group. Consequently, the activity of the catalyst would also decrease.

Table 3. Esterification reaction test results

\begin{tabular}{cccccc}
\hline No. & $\begin{array}{c}\text { Pyrolysis } \\
\text { Time } \\
\text { (hours) }\end{array}$ & $\begin{array}{c}\text { Pyrolysis } \\
\text { Temperature } \\
\left({ }^{\circ} \mathrm{C}\right)\end{array}$ & $\begin{array}{c}\text { Sulphonation } \\
\text { Time } \\
\text { (hours })\end{array}$ & $\begin{array}{c}\text { Sulphonation } \\
\text { Temperature } \\
\left({ }^{\circ} \mathrm{C}\right)\end{array}$ & $\begin{array}{c}\text { Conversion } \\
(\% \text {-wt. })\end{array}$ \\
\hline 1 & 12.5 & 350 & 15 & 150 & 98.157 \\
2 & 17.5 & 350 & 15 & 150 & 95.321 \\
3 & 12.5 & 450 & 15 & 150 & 90.217 \\
4 & 17.5 & 450 & 15 & 150 & 85.000 \\
5 & 15 & 400 & 15 & 150 & 97.448 \\
6 & 15 & 400 & 15 & 150 & 96.739 \\
7. & 15 & 400 & 15 & 150 & 97.022 \\
\hline
\end{tabular}

Table 4. Analysis of variance

\begin{tabular}{lcccccc}
\hline Source & $\begin{array}{c}\text { Sum of } \\
\text { Squares }\end{array}$ & DOF & $\begin{array}{c}\text { Mean } \\
\text { Square }\end{array}$ & F-value & p-value & \\
\hline Model & 101.00 & 3 & 33.67 & 264.30 & 0.0038 & significant \\
A- Pyrolysis Time & 16.21 & 1 & 16.21 & 127.28 & 0.0078 & significant \\
B- Pyrolysis Temperature & 83.37 & 1 & 83.37 & 654.50 & 0.0015 & significant \\
AB & 1.42 & 1 & 1.42 & 11.13 & 0.0793 & \\
Curvature & 41.09 & 1 & 41.09 & 322.60 & 0.0031 & significant \\
Pure Error & 0.25 & 2 & 0.13 & & & \\
Cor Total & 142.34 & 6 & & & & \\
\hline
\end{tabular}




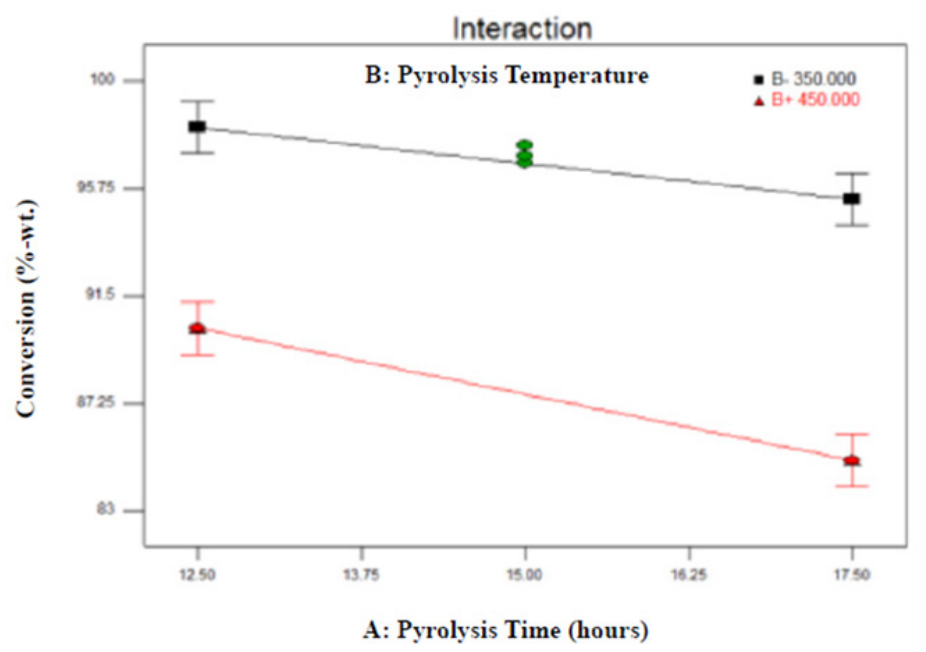

Figure 4. Effects of pyrolysis variables on the activity of the prepared catalysts

From the esterification reaction test, it is found that the catalyst obtained from pyrolysis at $400^{\circ} \mathrm{C}$ for 15 hours has the optimum $-\mathrm{SO}_{3} \mathrm{H}$ content of $5.9 \%$ which corresponds to the highest average conversion of the esterification of oleic acid of $97.45 \%$. The best performed catalyst in the esterification reaction test was then used to produce biodiesel from rubber seed oil using one stage acid catalyzed process.

The biodiesel product from one stage acid catalyzed process has the density of $0.899 \mathrm{~g} / \mathrm{mL}$, the kinematic viscosity of $6.29 \mathrm{~mm}^{2} / \mathrm{s}$, and the FFA content of $0.25 \%$. These values are slightly higher than the ASTM standard for biodiesel, indicating that the rubber seed oil has not been fully converted into biodiesel. A second stage acid or alkaline catalyzed process might be needed in order to complete the transesterification reaction of rubber seed oil so that the biodiesel product may conform to the ASTM standard requirement for biodiesel.

\section{Conclusions}

The pyrolysis time and temperature significantly affect the $-\mathrm{SO}_{3} \mathrm{H}$ content, hence the activity, of the prepared catalysts. At a shorter pyrolysis time, the formation of the polycyclic aromatic carbon rings in the carbonized material is imperfect. Sulphonating this material will result in a non-uniform distribution of the $-\mathrm{SO}_{3} \mathrm{H}$ group in the catalyst. At a lower pyrolysis temperature, the carbonized material tends to form a soft aggregate of small polycyclic aromatic carbon with $-\mathrm{SO}_{3} \mathrm{H}$ group. Therefore, the $-\mathrm{SO}_{3} \mathrm{H}$ group can be easily leached out from the catalyst. At a longer pyrolysis time and a higher pyrolysis temperature, the carbonized material tends to form a more rigid structure due to the growth of larger polycyclic aromatic carbon sheets and the stacking of carbon sheets that restricts its ability to adsorb the $-\mathrm{SO}_{3} \mathrm{H}$ group. The significant curvature in the response of the $-\mathrm{SO}_{3} \mathrm{H}$ content and the activity of the prepared catalysts indicate that the variable ranges selected in this study are in the optimum ranges. The catalyst obtained from pyrolysis at $400^{\circ} \mathrm{C}$ for 15 hours has the optimum $-\mathrm{SO}_{3} \mathrm{H}$ content of $5.9 \%$ which corresponds to the highest average conversion of the esterification of oleic acid of $97.45 \%$. The biodiesel produced from one stage acid catalyzed process using the best performed catalyst in the esterification reaction test has the density and the kinematic viscosity values that are slightly higher than the ASTM standard for biodiesel. This indicates that the rubber seed oil has not been fully converted into biodiesel. Further process might be needed in order to complete the transesterification reaction of rubber seed oil so that the biodiesel product may conform to the ASTM standard for biodiesel.

\section{Acknowledgments}

This research is supported by Direktorat Jendral Pendidikan Tinggi, Kementrian Pendidikan Nasional through Hibah Penelitian Unggulan Perguruan Tinggi 1102/K4/KM/2014.

\section{References}

Ahmia, A. C., Danane, F., Bessah, R., \& Boumesbah, I. (2014). Raw Material for Biodiesel Production. Valorization of Used Edible Oil. Revue des Energies Renouvelables, 17, 335-343.

Chen, G., \& Fang, B. (2011). Preparation of Solid Acid Catalyst from Glucose-Starch Mixture for Biodiesel Production. Bioresource Technology, 102, 2635-2640. http://dx.doi.org/10.1016/j.biortech.2010.10.099

Guo, Y., \& Leung, Y. C. (2003). Analysis on the Biodiesel Production Using Grease Trap Oils from Restaurants. 
Macro Review, Japan. Japan Macro-Engineer Society, 16, 421-426.

Ibeto, C. N., Ofoefule, A. U., \& Ezugwu, H. C. (2011). Analytical Methods for Quality Assessment of Biodiesel from Animal and Vegetable Oils. Trends in Applied Sciences Research, 6, 537-553. http://dx.doi.org/10.3923/tasr.2011.537.553

Kang, S., Ye, J., \& Chang, J. (2013). Recent Advances in Carbon-Based Sulfonated Catalyst: Preparation and Application, International Review of Chemical Engineering, 5, 133-144.

Lou, W. Y., Zong, M. H., \& Duan, Z. Q. (2008). Efficient Production of Biodiesel from High Free Fatty Acid-Containing Waste Oils Using Various Carbohydrate-Derived Solid Acid Catalysts. Bioresource Technology, 99, 8752-8758. http://dx.doi.org/10.1016/j.biortech.2008.04.038

Marchetti, J. M., Miguel, V. U., \& Errazu, A. F. (2007). Possible Methods for Biodiesel Production. Renewable and Sustainable Energy Reviews, 11, 1300-1311. http://dx.doi.org/10.1016/j.rser.2005.08.006

Mathiyazhagan, M., Ganapathi, A., Jaganath, B., Renganayaki, N., \& Sasireka, N. (2011). Production of Biodiesel from Non-Edible Plant Oils Having High FFA Content. International Journal of Chemical and Environmental Engineering, 2, 119-122.

Pimentel, D., Marklein, A., Toth, M. A., Karpoff, M. N., Paul, G. S., McCormack, R., Kyriazis, J., \& Krueger, T. (2009). Food Versus Biofuels: Environmental and Economic Costs. Human Ecology, 37, 1-12. http://dx.doi.org/10.1007/s10745-009-9215-8

Pua, F. L., Fang, Z., Zakaria, S., Guo, F., \& Chia, C. H. (2011). Direct Production of Biodiesel from High-Acid Value Jatropha Oil with Solid Acid Catalyst Derived from Lignin, Biotechnology for Biofuels, 4, 1-8. http://dx.doi.org/10.1186/1754-6834-4-56

Refaat, A. A. (2010). Different Techniques for the Production of Biodiesel from Waste Vegetable Oil. International Journal of Environmental Science and Technology, 7, 183-213. http://dx.doi.org/10.1007/BF03326130

Shu, Q., Gao, J., Nawaz, Z., Liao, Y., Wang, D., \& Wang, J. (2010). Synthesis of Biodiesel from Waste Vegetable Oil with Large Amounts of Free Fatty Acids Using a Carbon-Based Solid Acid Catalyst. Applied Energy, 87, 2589-2596. http://dx.doi.org/10.1016/j.apenergy.2010.03.024

Toda, M., Takagaki, A., Okamura, M., Kondo, J. N., Hayashi, S., Domen, K., \& Hara, M. (2005). Green Chemistry: Biodiesel Made with Sugar Catalyst. Nature, 438, 178. http://dx.doi.org/10.1038/438178a

Van Gerpen, J., \& Knothe, G. (2005). Basics of the Transesterification Reaction. In Knothe, G., Van Gerpen, J., \& Krahl, J. (Eds.), The Biodiesel Handbook (pp. 26-41). Urbana, Illinois: AOCS Press.

Wang, Y., Ou, S., Liu, P., \& Zhang, Z. (2007). Preparation of Biodiesel from Waste Cooking Oil via Two Step $\begin{array}{lllll}\text { Catalyzed Process. Energy Conversion } & \text { Manage., }\end{array}$ http://dx.doi.org/10.1016/j.enconman.2006.04.016

Zhang, Y., Dube, M. A., McLean, D. D., \& Kates, M. (2003). Biodiesel Production from Waste Cooking Oil: 2. Economic Assessment and Sensitivity Analysis. Bioresource Technology, 90, 229-240. http://dx.doi.org/10.1016/S0960-8524(03)00150-0

Zong, M. H., Duan, Z. Q., Lou, W. Y., Smith, T. J., \& Wu, H. (2007). Preparation of a Sugar Catalyst and Its Use for Highly Efficient Production of Biodiesel. Green Chemistry, 9, 434-437. http://dx.doi.org/10.1039/b615447f

\section{Copyrights}

Copyright for this article is retained by the author(s), with first publication rights granted to the journal.

This is an open-access article distributed under the terms and conditions of the Creative Commons Attribution license (http://creativecommons.org/licenses/by/3.0/). 